Reprod. Nutr. Dévelop., 1984, 24 (3), 251-263.

\title{
Glucagon kinetics in growing rats fed different levels of protein and/or energy
}

\author{
Michèle BALAGE, J. GRIZARD \\ with the collaboration of Marie-Louise HOULIER, Y. BONNET, M. SALLAS and A. SELLE \\ Laboratoire d'Etudes du Métabolisme azoté, I.N.R.A., \\ Theix, 63122 Ceyrat, France.
}

Summary. The present work was carried out to evaluate the kinetic parameters of glucagon in growing rats divided into three groups: $\mathrm{T}, \mathrm{H}$ and $\mathrm{E}$. Group T (Control group) was fed a control diet (crude protein : $11.8 \%$ ). Groups $\mathrm{H}$ and $\mathrm{E}$ received a high protein diet (crude protein : $19 \%$ ) distributed in either equal (Group H) or restricted amounts (Group E) with respect to the control. Thus, the main characteristic of Group $\mathrm{H}$ was the high level of protein intake $(+68 \%)$ when Group $E$ rats underwent a moderate increase in protein intake but a striking caloric deprivation ( $-25 \%)$. In all cases, the animals were fed a meal every 4 hours.

The kinetic parameters of glucagon metabolism were estimated from the plasma disappearance curves of ${ }^{125} \mathrm{I}$-glucagon for five minutes following a pulse injection of purified ${ }^{125}$ I-glucagon $\left(1 \mu \mathrm{Ci}\right.$, about $3.8 \mathrm{ng} / 100 \mathrm{~g}$ BW). Plasma ${ }^{125} \mathrm{I}$-glucagon was measured after gel filtration of plasma on Biogel P-10. Tissue radioactivity (mainly liver and kidneys) was recorded seven minutes after ${ }^{125}$-glucagon injection.

The results showed that the plasma ${ }^{125}$-glucagon level was higher in Group $\mathrm{H}$ than in the other groups $1 \mathrm{~min}$ after the injection. At all other times $(2,3.5$ and $5 \mathrm{~min})$ it was similar in all groups. ${ }^{125}$-glucagon was rapidly cleared from plasma and rapidly taken up by the liver and kidneys. In the 3 experimental groups, mean half-life and metabolic clearance rate were estimated to be $2 \mathrm{~min}$ and $6 \mathrm{ml} / \mathrm{min} / 100 \mathrm{~g} \mathrm{BW}$, respectively. Excess protein intake resulted in a reduction in the apparent initial distribution volume of ${ }^{125}$-glucagon without modifying significantly its turn-over rate and metabolic clearance rate. Kidneys and liver $(6 \% \mathrm{BW})$ accounted for about $20 \%$ of the ${ }^{125}$-glucagon uptake by tissues 7 min after injection. Group $\mathrm{H}$ kidneys and liver were more labelled than in other groups.

These results suggest that increased protein intake (without further caloric deprivation) can induce some changes in glucagon metabolism which could partially contribute to the increase in glucagonemia usually observed in animals fed high protein diets.

\section{Introduction.}

An increased dietary protein intake in growing animals results in an increase of body protein content (Henry and Rérat, 1965). On the other hand, a large excess of protein intake increases amino-acid extraction by the liver and gluconeogenesis (Peret et al., 1981 ; Fafournoux, Rémésy and Demigné, 1982). These 
metabolic adaptable responses could be correlated with an increment of glucagon effects on liver since this hormone enhances amino-acid transport ang gluconeogenesis in liver (Le Cam and Freychet, 1976; Fehlmann, Le Cam and Freychet, 1979 ; Fehlmann et al., 1981 ; Morin, Fehlmann and Freychet 1982 ; Parilla, Jimenez and Ayuso-Parilla, 1975, 1976). High levels of plasma glucagon have generally been associated with high protein diets (Tiedgen and Seitz, 1980 ; Eisenstein and Strack, 1978 ; Eisenstein et al., 1979 ; Péret et al., 1981). Changes in plasma hormone concentration may result from a stimulation of pancreatic $\alpha$ cells by amino acids (Dencker et al., 1975 ; Jarrousse et al., 1980), or a reduced hormonal clearance, or both.

In view of this, the possible influence of glucagon on the adaptation of growing rats to a high protein intake was investigated. The metabolic clearance rate of glucagon and the uptake of this hormone by various tissues were studied. For this purpose, a pulse injection of ${ }^{125} \mathrm{I}$-glucagon into the jugular vein was performed. Labelled glucagon was used in order to avoid problems inherent in a lack of glucagon antibody specificity. The studies of Valverde et al. $(1975,1976)$ and Jaspan et al. (1976) made it clear that immunoreactive glucagon (IRG) fractions other than true glucagon were present in plasma and cross-reacted with highly specific antibodies. Nevertheless, ${ }^{125}$-glucagon metabolism may differ from that of unlabelled hormone, as demonstrated in insulin metabolism (Genuth, 1972 ; Sherwin et al., 1974).

To remain within reasonable nutritional conditions, an experimental model was conceived to enhance protein intake without decreasing carbohydrate intake (Group H). The ad libitum feeding of very high protein diets usually decreases daily consumption, which induces further caloric deprivation. The possible specific influence of such a restriction was assessed in another experimental model, which showed a moderate increase in protein intake but impaired caloric intake (Group E).

\section{Material and methods.}

Preparation of $125 \mathrm{~J}$-g/ucagon. - ${ }^{125} \mathrm{~J}$-glucagon was prepared according to the method of Nottey and Rosselin (1971) with highly purified porcine glucagon (Novo, Bagsvaerd, Denmark, lot G 501575) and ${ }^{125} \mathrm{I}-\mathrm{Na}$ (Amersham, England, IMS 30). It was purified by chromatography on a DEAE cellulose column equilibrated with $0.05 \mathrm{M}$ Tris buffer $\mathrm{pH} 9.3$ and eluted by $\mathrm{NaCl}$ gradient $(0-0.5 \mathrm{M})$. The mean specific activity of ${ }^{125} \mathrm{~J}$-glucagon, determined by self-displacement of the tracer in a radioligand receptor assay, ranged from 110 to $270 \mu \mathrm{Ci} / \mu \mathrm{g}$. Thus the preparation contained 15 to $40 \%$ of ${ }^{125} \mathrm{I}$-glucagon and 60 to $85 \%$ of unlabelled glucagon.

Animals and treatments. - Thirty-tree male Sprague Dawley rats weighing about $50 \mathrm{~g}$ were purchased and housed individually in cages under controlled environmental conditions $\left(22^{\circ} \mathrm{C} ; 60 \%\right.$ relative humidity, 12 hrs dark period starting at $11.00 \mathrm{~h}$ ).

Until the rats reached $70 \mathrm{~g}$, they were allowed free access to a standard commercial diet. From 70 to $95 \mathrm{~g}$, they were fed a balanced diet containing 
$11.8 \%$ crude protein provided in six equal meals spaced evenly over the daynight cycle by means of an automatic feeding system. When adapted to this device, the animals were divided into three groups: T, H and $E$. The rats of Group $T$ were fed the control diet, those of Groups $H$ and $E$ received a high protein diet (about $19 \%$ crude protein) given in the same amounts (Group H) as those of the controls (Group T) or in restricted amounts (Group E) $(-28 \%$ ) (table 1).

TABLE 1

Diet composition $(\mathrm{g} / \mathrm{kg}$ of dry matter).

\begin{tabular}{|c|c|c|c|}
\hline Group & Control & $\begin{array}{l}\text { Expe } \\
H\end{array}$ & $\begin{array}{c}\text { ental } \\
E\end{array}$ \\
\hline 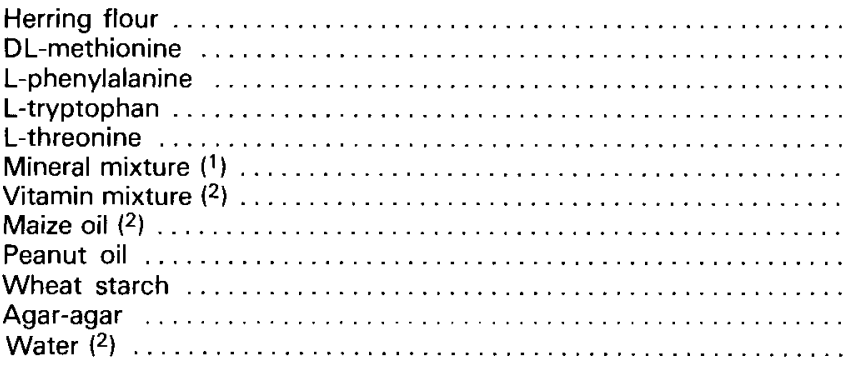 & $\begin{array}{l}146 \\
1.3 \\
1.0 \\
0.5 \\
0.8 \\
40 \\
20 \\
20 \\
52 \\
682 \\
35 \\
950\end{array}$ & $\begin{array}{l}240 \\
1.0 \\
0.8 \\
0.4 \\
0.6 \\
32 \\
20 \\
20 \\
25 \\
625 \\
35 \\
950\end{array}$ & $\begin{array}{c}242 \\
2.2 \\
1.7 \\
0.8 \\
1.3 \\
67 \\
33 \\
33 \\
33 \\
551 \\
35 \\
950\end{array}$ \\
\hline 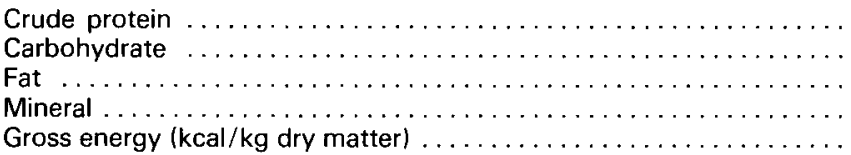 & $\begin{array}{r}118 \\
714 \\
80 \\
53 \\
4339\end{array}$ & $\begin{array}{r}192 \\
660 \\
59 \\
54 \\
4343\end{array}$ & $\begin{array}{r}197 \\
600 \\
80 \\
88 \\
4315\end{array}$ \\
\hline
\end{tabular}

(1) Mineral mixture plus minerals present in herring flour met mineral needs of growing rats (Pawlak and Pion, 1968 ; Grizard et al., 1975).

(2) Vitamin mixture contained vitamins B12, E, K1, B1, PP, B6, B2, folic acid, calcium panthotenate, cyclohexanehexol and aminobenzoic acid.

Vitamins A and D2 were added to maize oil. Choline and biotin were added in water solutions.

Daily crude protein intake was higher in the experimental groups $1+68 \%$ in Group $\mathrm{H}$ and $+22 \%$ in Group E) than in the control group (table 2). In contrast to Group $H$, Group $E$ carbohydrate intake was significantly lower $(-38 \%)$; consequently the animals were subjected to a drastic energy restriction $(-25 \%)$. The experimental period was conducted until the rats reached $155-160 \mathrm{~g}$; the total experimental periods lasted $10-12,7-10$ and 16-19 days for Groups $T, H$ and $E$, respectively. All the animals had free access to water.

When the rats reached a mean body weight of $125 \mathrm{~g}$ (Groups $\mathrm{T}$ and $\mathrm{H}$ ) or $140 \mathrm{~g}$ (Group E), catheters (subcutaneous part, length : $140 \mathrm{~mm}$; i.d. : $0.58 \mathrm{~mm}$; o.d. : $0.96 \mathrm{~mm}$, polyethylene Biotrol $\mathrm{N}^{\circ} 3$; intravascular part, length : $25 \mathrm{~mm}$; i.d. : $0.30 \mathrm{~mm}$; o.d. : $0.64 \mathrm{~mm}$, Silastic) were inserted into the two jugular veins under chloral anesthesia, according to the technique of Jarrige et al. (1978). They remained in situ for 5-6 days. Each catheter was checked and rinsed daily with $0.2 \mathrm{ml}$ of saline containing heparin $(50 \mathrm{IU} / \mathrm{ml})$. At a mean body weight of $157 \mathrm{~g}$, 
TABLE 2

Animal characteristics.

\begin{tabular}{|c|c|c|c|}
\hline \multirow{2}{*}{ Group } & \multirow{2}{*}{$\begin{array}{c}\text { Control } \\
T\end{array}$} & \multicolumn{2}{|c|}{ Experimental } \\
\hline & & $\mathrm{H}$ & $\mathrm{E}$ \\
\hline $\begin{array}{l}\text { Number of animals } \ldots \ldots \ldots \ldots \ldots \ldots \ldots \ldots \\
\text { Experimental period }(\mathrm{d}) \ldots \ldots \ldots \ldots \ldots \ldots \ldots \\
\text { Initial liveweight }(\mathrm{g}) \ldots \ldots \ldots \ldots \ldots \ldots \ldots \\
\text { Liveweight at slaughter }(\mathrm{g}) \ldots \ldots \ldots \ldots \ldots \ldots\end{array}$ & $\begin{array}{c}12 \\
10-12 \\
92 \pm 4 \\
159 \pm 6\end{array}$ & $\begin{array}{c}11 \\
7-10 \\
93 \pm 5 \\
157 \pm 4\end{array}$ & $\begin{array}{c}10 \\
16-19 \\
97 \pm 4 \\
156 \pm 3\end{array}$ \\
\hline \multicolumn{4}{|l|}{ Daily intake before surgery. } \\
\hline 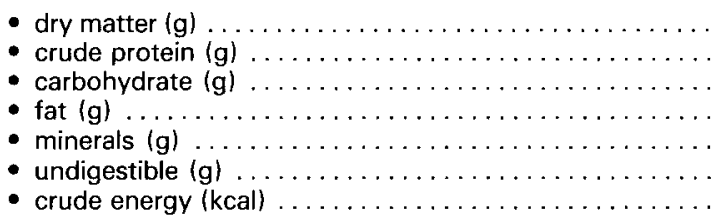 & $\begin{array}{l}13.1 \pm 0.5 \\
1.55 \\
9.36 \\
1.05 \\
0.76 \\
0.46 \\
57\end{array}$ & $\begin{array}{c}13.5 \pm 0.6 \\
2.59^{\mathrm{t}} \\
8.91^{\mathrm{t}} \\
0.79^{\mathrm{t}} \\
0.72 \\
0.47 \\
59\end{array}$ & $\begin{array}{l}9.7 \pm 0.3^{\text {th }} \\
1.9^{\text {th }} \\
5.8^{\text {th }} \\
0.77^{\text {t }} \\
0.95^{\text {th }} \\
0.34^{\text {th }} \\
42^{\text {th }}\end{array}$ \\
\hline \multicolumn{4}{|l|}{ Daily intake of dry matter after surgery $(g)}$. \\
\hline & $14.3 \pm 1.0$ & $14.5 \pm 1.2$ & $10.8 \pm 0.8^{\text {th }}$ \\
\hline
\end{tabular}

Each value is the mean $\pm S D ; t$ : significantly different $(P<0.05)$ from the controls ; $h$ : significantly different $(P<0.05)$ from group $H$.

$1 \mu \mathrm{Ci}$ of ${ }^{125}$-glucagon (about $3.8 \mathrm{ng} / 100 \mathrm{~g} \mathrm{B.W.}$ ) was rapidly injected intravenously into the right catheter. To estimate the disappearance of the injected ${ }^{125}$-glucagon from the circulation, four blood samples, collected from the left catheter (the total volume of blood collected did not exceed $2 \mathrm{ml}$ ) at 1, 2, 3.5 and 5 min after ${ }^{125} \mathrm{I}$-glucagon injection, were placed in heparinized tubes containing bacitracin and aprotinin (Sigma Chem. Co., USA) in concentrations of $0.1 \mathrm{mg}$ and $100 \mathrm{IU}$, respectively, per $\mathrm{ml}$ of blood removed. The plasma was rapidly separated and stored in an ice bath until analysis (the dilution of plasma by glucagon catabolism inhibitors was taken into account in further calculations). In each group, the injections were carried out at different times in the dark period over a complete post-prandial period (i.e. 0.5, 1, 1.5, 2.5, 3 and 3.5 hours after the meal). The measurements were only performed during the $1-3 \mathrm{~h}$ post-prandial period. Since no significant relationship between kinetic parameters of glucagon and post-feeding intervals was observed, the means in the different groups were compared.

Plasma ${ }^{125} \mathrm{I}$-g/ucagon measurements. - Plasma ${ }^{125} \mathrm{I}$-glucagon was determined after gel filtration of plasma onto $50 \times 1 \mathrm{~cm}$ Biogel $P 10$ columns. Elution was carried out under gravity at $+4{ }^{\circ} \mathrm{C}$ with $0.2 \mathrm{M}$ glycine buffer $(\mathrm{pH} \mathrm{8.8)}$. Onemilliliter fractions were collected and counted for radioactivity. The radioactivity recovered after elution was constant and represented about $92 \%$ of the total radioactivity applied to the columns. The ${ }^{125} \mathrm{I}$-glucagon solution used for injections was mixed with rat serum and chromatographed on Biogel P 10 every day before use to detect possible hormone degradation. During the entire experimental period, 76 to $83 \%$ of the radioactivity was eluted in the volume of native glucagon. All further calculations were corrected for this degradation. 
Distribution of radioactivity in liver and kidneys. - Immediately after blood sample collection (i.e. about seven $\min$ after ${ }^{125}$-glucagon injection), the rats were bled without anesthesia. The liver, kidneys and other organs and tissues (muscle, lungs, heart, spleen, pancreas, bone and skin) were rapidly removed, rinsed in saline, blotted, weighed and counted for radioactivity.

Data analysis. - The kinetic parameters of glucagon metabolism were calculated assuming that ${ }^{125} \mathrm{~J}$-glucagon was distributed in one homogeneous compartment (the decay curves, plotted on a semi-logarithmic scale, were monoexponential for $5 \mathrm{~min}$ after injection). The turnover rate $(\mathrm{K})$ was determined as the slope of the linear regressions of the logarithm of plasma ${ }^{125} \mathrm{~J}$-glucagon level $v s$ time. These regression lines were extrapolated to zero time to determine the theoretical initial ${ }^{125} \mathrm{I}$-glucagon level (Co) (expressed as $\%$ of injected dose/g plasma). The initial distribution volume (IDV), half-life (T 1/2) and metabolic clearance rate (MCR) of ${ }^{125} \mathrm{I}$-glucagon were obtained by the respective formulae :

IDV $=1 /$ Co ; T $1 / 2=0.693 / \mathrm{K} ; \mathrm{MCR}=\mathrm{IDV} \times \mathrm{K}$. Linear unweighted regressions were used. Comparisons between groups were performed by variance and covariance analysis (Snedecor and Cochran, 1971).

\section{Results.}

Animal growth rate. - The mean growth rate was very high in rats from Groups $\mathrm{T}$ and $\mathrm{H}$. It was significantly increased in Group $\mathrm{H}$ when compared to

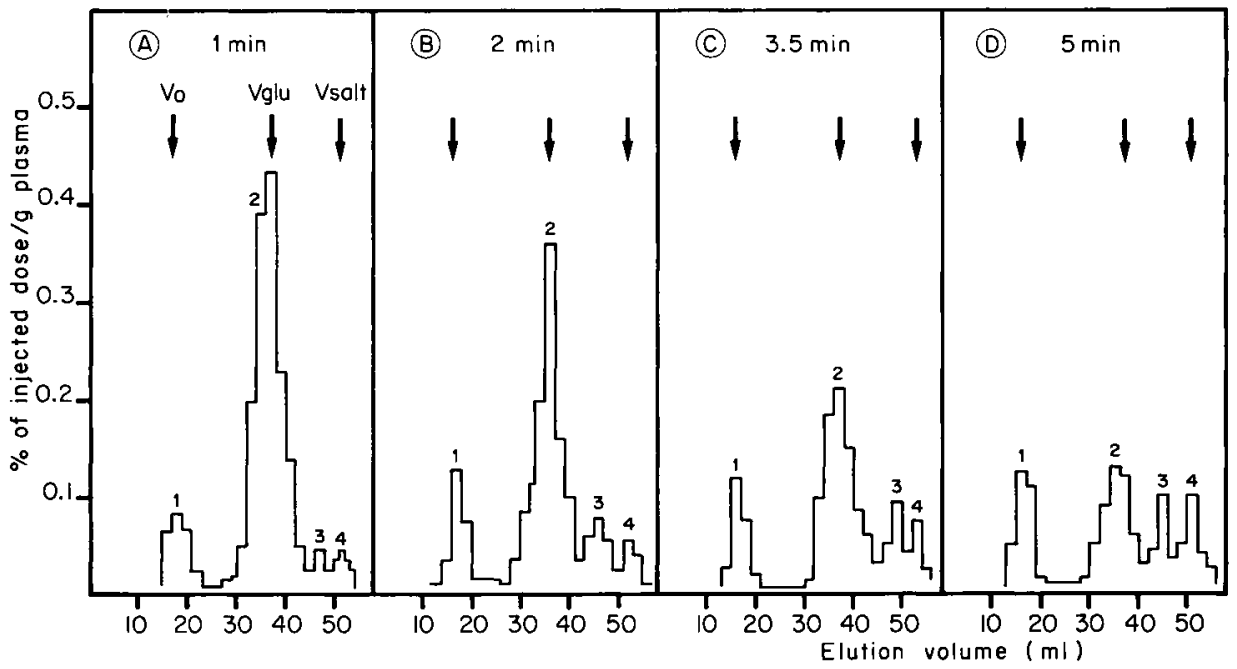

FIG. 1. - Evolution profile of plasma radioactivity $1,2,3.5$ and $5 \mathrm{~min}$ after $\mathrm{N}$ injection of $125 /$ g/ucagon into growing rats. ${ }^{125}$-glucagon $(1 \mu \mathrm{Ci})$ was injected as a bolus into an external jugular vein of non-anesthetized rats. Blood samples were drawn from the other jugular vein. Plasma was filtered on Biogel P-10 columns $(50 \times 1 \mathrm{~cm}) ; 1 \mathrm{ml}$ fractions were collected by elution at $+4^{\circ} \mathrm{C}$ with $0.2 \mathrm{M}$ glycine buffer $(\mathrm{pH} 8.8$ ). Arrows indicate void volume (Vo, peak 1), elution volume of standard labelled glucagon (V Glu, peak 2), elution volume of products with molecular weight ranging between $125 \mathrm{~F}$-glucagon and salt (peak 3), and elution volume of small molecular weight compounds ( $V$ salt, peak 4). The data are plotted as \% of total injected radioactivity/g plasma/ml eluat. The profiles correspond to a typical experiment on one animal from group $H$. 
Group $\mathrm{T}(7.2$ vs $5.7 \mathrm{~g}$ per day, $\mathrm{P}<0.05)$. However this increase must be considered critically since the experimental period in Group $\mathrm{H}$ was too short to allow any accurate growth rate estimation. The growth rate decreased slightly after surgery in Groups $T$ and $H(5.4$ and $6.6 \mathrm{~g}$ per day in Group $T$ and $H$, respectively). This was due to the low level of daily dry matter intake $(14.4 \mathrm{~g})$ (table 2) ; 17-18 g were usually recorded in non-operated rats of the same weight undergoing the control diet. Growth rate was greatly reduced in rats from Group $\mathrm{E}$ (about $3 \mathrm{~g}$ per day) but was not altered by surgery.

Evolution of plasma total radioactivity and 125 -g/ucagon. - Plasma radioactive material eluted mainly as 4 peaks (fig. 1) from the column of Biogel $\mathrm{P}-10$. The first was eluted in the void volume (peak 1), the second in the elution volume of ${ }^{125}$ I-glucagon (peak 2), the third in a volume corresponding to a molecular weight ranging between ${ }^{125} \mathrm{I}$-glucagon and amino acids (peak 3 ), and the fourth in a volume corresponding to ${ }^{125} \mathrm{~J}$-Tyr or ${ }^{125}$ ( peak 4).

Figure 2 depicts the evolution of the different forms of radioactivity in the plasma as estimated by gel chromatography in the five-minute period after ${ }^{125}$ I-glucagon injection. In all groups, the total plasma radioactivity rapidly declined after injection (fig. 2A). This decrease resulted mainly from the disappearance of ${ }^{125}$ I-glucagon from plasma which declined more quickly than total radioactivity (fig. 2B). In contrast, radioactive ${ }^{125} \mathrm{I}$-glucagon breakdown products remained steady between 1 and $5 \mathrm{~min}$ after the bolus injection (fig. 2C). One min after injection, both the total radioactivity and ${ }^{125}$-glucagon radioactivity were

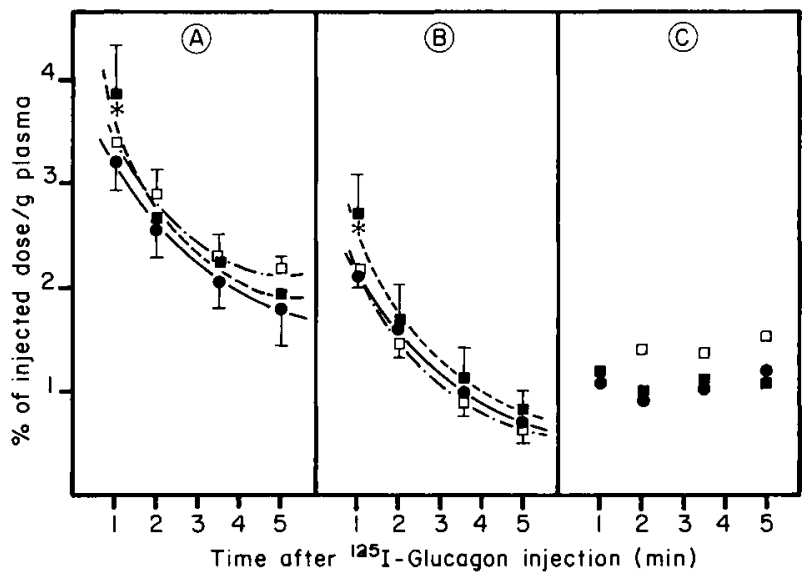

FIG. 2. - Evolution of the different forms of plasma radioactivity following intravenous injection of 125 -glucagon in growing rats subjected to a balanced diet $\left(--0_{0}\right.$ : control group T); excess protein intake (-- -- : group $\mathrm{H})$ or energy restriction plus a moderate excess of protein intake (-.$\square$-.- : group E) (means \pm SD). At time 0, 125 -glucagon (about $1 \mu \mathrm{Ci}$ ) was injected as a bolus into an external jugular vein of non-anesthetized rats. Blood samples were drawn from the other jugular vein at varying times after ${ }^{125}$-glucagon injection. Plasma radioactivities were determined after gel filtration of plasma on Biogel P-10.

* : significantly different $(P<0.05)$ from the corresponding values observed at the same time after injection in the other groups.

A : Total radioactivity ; $\mathrm{B}:{ }^{125} \mathrm{I}$-glucagon radioactivity ; $\mathrm{C}$ : Radioactivity eluted in the high and low molecular weight region. 
significantly higher $(\mathrm{P}<0.05)$ in Group $\mathrm{H}$ than in the other two groups. At longer intervals (i.e. $2,3.5$ and 5 min after injection) they were similar in the 3 groups.

Calculated kinetic parameters of glucagon metabolism. - During the 5 min following ${ }^{125} \mathrm{I}$-glucagon administration, the decay curves of plasma ${ }^{125} \mathrm{I}$-glucagon could be fitted as a straight line when plotted on semi-logarithmic coordinates in each group (fig. 3) ; the mean regression lines were highly significant $(P<0.001)$. Thus, the kinetic parameters of ${ }^{125} /$-glucagon metabolism could be reasonably calculated, assuming that ${ }^{125} \mathrm{I}$-glucagon was distributed in one homogeneous compartment. However this must be accepted with caution (see Discussion).

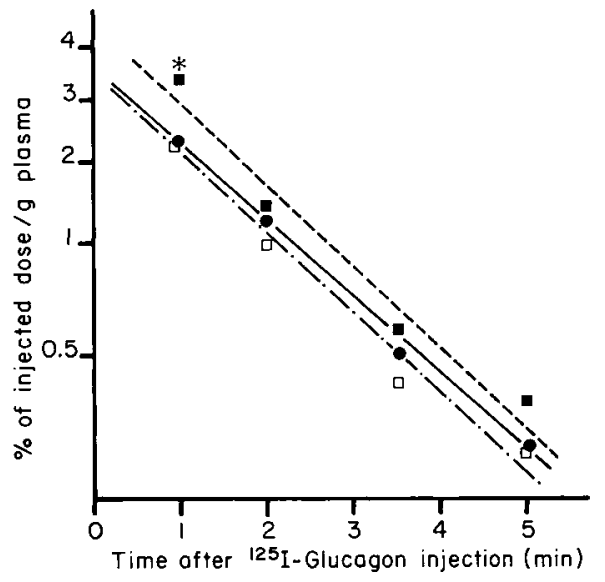

FIG. 3. - Semi-logarithmic plots of the decrease in 125/-glucagon from plasma presented in Fig. 2. Kinetic parameters were calculated from regression lines as described in "Material and methods " (- - group $\mathrm{T} ;--\mathbf{-}-$ group $\mathrm{H} ;-\cdot-\sqcup \cdot-\cdot-$ group $\mathrm{E}$ ).

* : significantly different $\left(P^{\prime}<0.05\right)$ from the corresponding values observed at the same time after injection in the other groups.
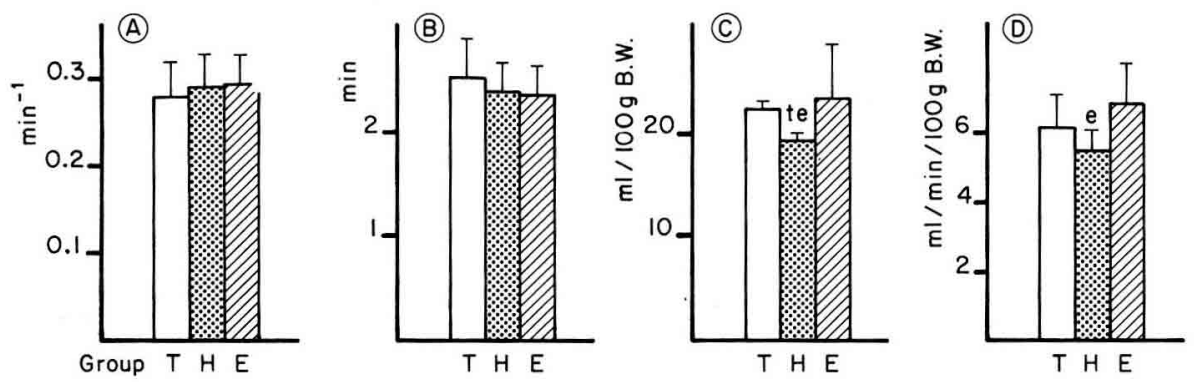

FIG. 4. - Apparent kinetic parameters of $125 /$ g/ucagon metabolism (means \pm SD). Kinetic parameters were calculated from the decay curves of plasma ${ }^{125}$-glucagon disappearance (Fig. 2B) plotted on semi-logarithmic coordinates (Fig. 3) assuming that 125/-glucagon was distributed in a homogeneous compartment.

$t$ : significantly different $(P<0.05)$ from the control value.

$e$ : significantly different $(P<0.05)$ from the group $E$ value.

A : Turn-over rate ; B : Half-life ; C : Initial distribution volume ; D : Metabolic clearance rate. 
The apparent turn-over rate and half-life of ${ }^{125}$-glucagon were constant whatever the nutritional conditions of the animals (fig. 4). Apparent distribution volume and metabolic clearance rate were high $(20 \mathrm{ml} / 100 \mathrm{~g} \mathrm{BW}$ and $6 \mathrm{ml} / \mathrm{min} / 100 \mathrm{~g}$ BW, respectively). The apparent distribution volume was significantly decreased $(P<0.05)$ in Group $H$ when compared to the other groups. It was similar in Groups $T$ and $E$. The apparent metabolic clearance rate was slightly reduced in Group $\mathrm{H}$ when compared to the other groups; the difference became significant $(P<0.05)$ when compared with Group $E$.

Distribution of radioactivity in liver and kidneys 7 min after ${ }^{125} /$-glucagon injection. - The concentration of radioactivity recovered in some tissues $7 \mathrm{~min}$ after ${ }^{125}$ I-glucagon injection was not significantly modified in the 3 groups (table 3). In each group it was very high in kidneys (about $10 \%$ of the injected

TABLE 3

Radioactivity in tissues (\% of the injected dose $/ g, \pm \mathrm{SD}$ ).

\begin{tabular}{|c|c|c|c|}
\hline \multirow{2}{*}{ Group } & \multirow{2}{*}{$\begin{array}{l}\text { Control } \\
T\end{array}$} & \multicolumn{2}{|c|}{ Experimental } \\
\hline & & $\mathrm{H}$ & $\mathrm{E}$ \\
\hline Kidneys & $9.25 \pm 1.0$ & $10.8 \pm 1.0$ & $10.3 \pm 1.4$ \\
\hline Liver & $1.08 \pm 0.18$ & $1.6 \pm 0.6$ & $1.09 \pm 0.1$ \\
\hline Pancreas & $\overline{1.2}$ & $0 . \overline{9}$ & 0.9 \\
\hline Lungs .. & 0.8 & 0.7 & 0.9 \\
\hline Spleen & 0.6 & 0.6 & 0.6 \\
\hline Heart. & 0.5 & 0.6 & 0.5 \\
\hline Skin & 0.5 & 0.5 & 0.6 \\
\hline Bone & 0.4 & 0.4 & 0.4 \\
\hline Muscle & 0.5 & 0.5 & 0.5 \\
\hline
\end{tabular}

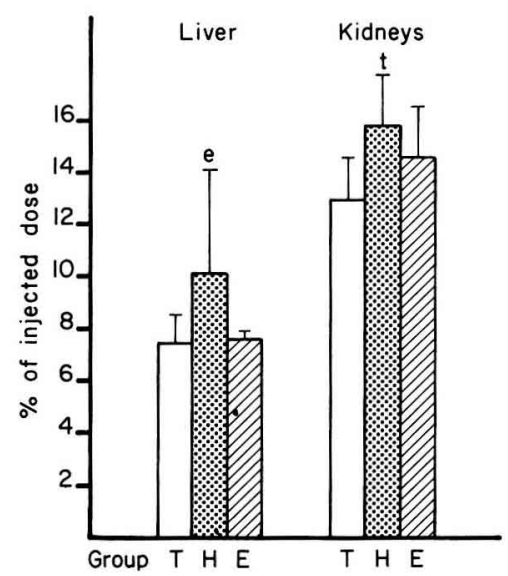

FIG. 5. - Distribution of radioactivity in liver and kidneys of rats following $125 /$-glucagon injection (means \pm SD)

About seven min after injection, the rats were bled without anesthesia. The liver and kidneys were rapidly removed and counted for radioactivity. In each group, results were expressed as the percentage of the total injected radioactivity recovered from each organ.

$t=$ values of group $H$ significantly different $(P<0.05)$ from the corresponding values in group $T$. $\mathrm{e}=$ values of group $\mathrm{H}$ significantly different $(\mathrm{P}<0.05)$ from the corresponding values in group $\mathrm{E}$. 
dose per g). The liver, pancreas and lungs also exhibited consistent labelling. In contrast, the radioactivity level was very low in all the other tissues (table 3 ).

The amount of radioactivity in liver was slightly enhanced in Group $\mathrm{H}$ when compared to the other groups (fig. 5), but not significantly $(0.05<P<0.10)$. On the other hand the amount of radioactivity present in kidneys was significantly higher $(P<0.05)$ in Group $H$ than in Group $T$.

\section{Discussion.}

Injected ${ }^{125} \mathrm{I}$-glucagon was rapidly cleared from plasma. This agrees with other published works (Alford, Bloom and Nabarro, 1976 ; Fisher et al., 1976 ; Sherwin et al., 1976; Van Hoorn, Vinik and Van Hoorn-Hickman, 1978 ; Brockman, 1980 ; Jaspan et al., 1981 ; Hayashi, 1982), but the apparent half-life and metabolic clearance rate values were respectively smaller $(2 \mathrm{~min}$ vs 3-5 min) and higher $(6 \mathrm{ml} / \mathrm{min} / 100 \mathrm{~g} \mathrm{BW}$ vs $0.5-1.5 \mathrm{ml} / \mathrm{min} / 100 \mathrm{~g} \mathrm{BW})$ than those obtained in most works referred to. This discrepancy may be partially explained by the use of a pulse injection technique instead of a constant infusion technique. Indeed, during the short period after ${ }^{125} \mathrm{I}$-glucagon injection, the disappearance of ${ }^{125} \mathrm{I}$-glucagon from the circulation involved both tissue uptake and diffusion into the blood and some areas of the extracellular space. Furthermore, all quoted works were performed in species other than rats, using unlabelled hormone. The amount of ${ }^{125} \mathrm{I}$-glucagon injected (i.e. about $3.8 \mathrm{ng} / 100 \mathrm{~g} \mathrm{BW}$ ) might not have interfered since a large increase in glucagonemia after the infusion of native hormone did not modify glucagon metabolism (Fisher et al., 1976 ; Alford, Bloom and Nabarro, 1976).

Seven $\min$ after ${ }^{125} \mathrm{~F}$-glucagon injection, about $20 \%$ of the total injected radioactivity was present in liver and kidneys which represent only $6 \%$ of the whole body mass (the radioactivity present in other tissues was always less than $1 \%$ per $\mathrm{g}$ of tissue). This suggests that ${ }^{125} \mathrm{I}$-glucagon was greatly taken up by the liver and kidneys and confirms that these organs are major sites of glucagon metabolism (Lefebvre, Luyckx and Nizet, 1974; Lefebvre and Luyckx, 1976 ; Sherwin et al., 1976 ; Jaspan et al., 1977, 1981). The high level of radioactivity in kidneys when compared to liver agrees with further studies (Balage, 1983) which show that radioactivity accumulates in kidneys during the first 10 min following injection, whereas it displays a decay curve in liver. Furthermore, during this period, the radioactivity associated with liver can be displaced in vivo by unlabelled glucagon, according to a time-related dose-response curve suggesting that a large part of injected ${ }^{125} \mathrm{I}$-glucagon is bound specifically and reversibly to liver structures (e.g. plasma membrane receptors). This is in good agreement with previous observations from direct studies of radioactivity in subcellular fractions of liver (Desbuquois and Postel-Vinay, 1980 ; Barazzone et al., 1980).

In view of this, it may be inferred that the apparent distribution of glucagon in one homogeneous compartment (as suggested by the decay curve of plasma ${ }^{125} \mathrm{I}$-glucagon according to a mono-exponential equation) masks a very heterogeneous distribution space which might involve both distribution in physical 
spaces (e.g. in plasma and extracellular fluid of strongly irrigated organs) and accumulation on cellular receptors. Thus, the meaning of the calculated distribution volume must be considered critically.

Effect of experimental diets. - One minute after injection, the plasma ${ }^{125} \mathrm{I}$-glucagon level was significantly higher in Group $\mathrm{H}$ than in other groups. This high level did not result from a modified turn-over rate of ${ }^{125} \mathrm{I}$-glucagon since there was no change in the three groups. The calculations showed that it could be explained by a decrease in the apparent initial distribution volume of the hormone in the animals of Group $\mathrm{H}$. As stated above, this apparent distribution volume involved glucagon receptors; so, impaired glucagon binding could have decreased this volume, as demonstrated for insulin by Zeleznick and Roth (1978). This seems unlikely since, in vitro, specific glucagon binding to purified liver plasma membranes of Group $\mathrm{H}$ animals was unchanged (Balage, 1983). Nevertheless, $7 \mathrm{~min}$ after ${ }^{125} \mathrm{I}$-glucagon injection, the radioactivity present in the liver was slightly higher in Group $\mathrm{H}$, suggesting a rise of ${ }^{125} \mathrm{I}$-glucagon uptake in vivo. The decrease in physical distribution space could result from a modification in rat body composition after feeding the high protein diet. For example, liver protein concentration was significantly increased in Group $\mathrm{H}(184 \mathrm{mg} / \mathrm{g}$ vs 174).

The high level of plasma ${ }^{125} \mathrm{I}$-glucagon $1 \mathrm{~min}$ after injection and the small reduction of the metabolic clearance rate of the hormone in rats subjected to an excess of protein intake are in good agreement with the rise of plasma glucagon levels usually observed in animals fed high protein diets (Tiedgen and Seitz, 1980 ; Eisenstein and Strack, 1978 ; Eisenstein et al., 1979 ; Peret et al., 1981) or proteins as a single meal (Jarrousse et al., 1980). Nevertheless, a decrease in metabolic clearance rate such as the one observed in rats of Group $\mathrm{H}$ cannot explain the development of hyperglucagonemias as high as those observed in the studies quoted above, or as observed in fasting man by Fisher et al. (1976). However the comparison must be made with caution because the rise in glucagonemia in the present study should be of less magnitude than that obtained in studies previously mentioned since the excess protein intake is not so high (68\% vs $150-250 \%$ excess).

Seven min after ${ }^{125}$-glucagon injection, the radioactivity present in kidneys and liver was high in Group $\mathrm{H}$ when compared to Group $\mathrm{T}$. This is not in keeping with either the decrease in apparent distribution space of the hormone or the unchanged liver glucagon receptors in such animals, the latter suggesting constant tissue uptake. The high hepatic radioactivity might be attributed to an increment of ${ }^{125} \mathrm{I}$-glucagon half-life in the liver, particularly on membrane receptors, as previously discussed for insulin by Sodoyez et a/. (1980). However the meaning of whole liver radioactivity must be considered critically since the nature of the radioactive compounds and their distribution in cellular fractions of liver are not known. Further investigations are needed to find out the origin of this improvement.

Surprisingly, the high protein intake noted in Group E did not alter glucagon metabolism. This could be explained by the fact that the increase in protein intake was moderate $(+25 \%)$ and was linked to a strong caloric deprivation. In addition, the length of the adaptation period differed appreciably between 
Group $E$ and the other groups (table 2). It has previously been reported that the effects of a high protein diet on glucagonemia may be correlated with the length of the adaptation period (Peret et al., 1981).

In conclusion, an increased protein intake in growing rats induced some modifications in glucagon metabolism, such as a reduction in the initial distribution space and in the metabolic clearance rate of the hormone. The latter could partially contribute to the increase in glucagonemia generally induced by high protein diets. Further caloric deprivation counteracted the effect of an excess protein intake.

Reçu en août 1983.

Accepté en décembre 1983.

Résumé. Métabolisme du glucagon chez le rat en croissance: influence des protéines et/ou de l'énergie ingérées.

Ce travail a été réalisé afin d'étudier les caractéristiques du métabolisme du glucagon chez des rats en croissance répartis en 3 groupes : T, H et $E$. Les animaux du groupe $T$ (Témoins) reçoivent un régime témoin équilibré $(11,8 \%$ de matières azotées). Les animaux des groupes $\mathrm{H}$ et $\mathrm{E}$ reçoivent un régime riche en protéines (19\% de matières azotées) distribué soit en quantité équivalente à celle que reçoivent les animaux Témoins (groupe $H$ ) soit en quantité limitée (groupe E). Aussi le groupe $\mathrm{H}$ se caractérise par une nette augmentation des quantités de protéines ingérées $(+68 \%)$ alors que les animaux du groupe $E$ sont soumis à une forte diminution de l'énergie ingérée $(-25 \%)$. Dans tous les cas, l'aliment est distribué en 6 repas égaux régulièrement répartis au cours du nycthémère.

Les paramètres cinétiques du métabolisme du glucagon sont déterminés à la suite d'une injection unique de ${ }^{125}$-glucagon $(1 \mu \mathrm{Ci}$, environ $3,8 \mathrm{ng} / 100 \mathrm{~g}$ de poids vif) par l'étude de l'évolution de la teneur plasmatique en ${ }^{125}$-glucagon au cours des 5 min suivant l'injection. Le ${ }^{125}$-glucagon plasmatique est mesuré après filtration des plasmas sur Biogel P-10. La distribution de la radioactivité dans plusieurs tissus (principalement le foie et les reins) est mesurée environ 7 min après l'injection de ${ }^{125}$ I-glucagon.

Une minute après I'injection la teneur plasmatique en ${ }^{125} \mathrm{I}$-glucagon est plus élevée chez les animaux du groupe $\mathrm{H}$. Elle est identique dans tous les lots pour les autres temps $12-3,5$ et 5 min après l'injection). Le ${ }^{125} \mathrm{I}$-glucagon est rapidement prélevé et métabolisé par le foie et le rein. Dans chacun des 3 groupes d'animaux, la demi-vie et le taux de clairance métabolique du ${ }^{125} \mathrm{I}$-glucagon sont estimés respectivement à $2 \mathrm{~min}$ et $6 \mathrm{ml} / \mathrm{min} / 100 \mathrm{~g}$ poids vif. L'excès de protéines ingérées entraîne une réduction du volume de distribution initial apparent de I'hormone sans modification significative de son taux de renouvellement et de son taux de clairance métabolique. Les reins et le foie (6\% du poids vif) représentent environ $20 \%$ du prélèvement tissulaire du glucagon 7 min après l'injection. La radioactivité retrouvée dans le foie et le rein est plus élevée chez les rats du groupe $\mathrm{H}$ que chez les rats des autres groupes.

L'augmentation de l'ingestion des protéines (sans diminution de l'énergie ingérée) entraîne certaines modifications du métabolisme du glucagon qui pourraient contribuer partiellement à l'augmentation de la glucagonémie habituellement observée chez les animaux recevant des régimes riches en protéines.

\section{References}

ALFORD F. P., BLOOM S. R., NABARRO J. D. N., 1976. Glucagon metabolism in man Studies on the metabolic clearance rate and the plasma acute disappearance time of glucagon in normal and diabetic subjects. J. clin. Endocrinol. Metab., 42, 380-838.

BALAGE M., 1983. Métabolisme et récepteurs hépatiques du glucagon chez le rat en croissance. Influence des protéines ingérées. Thèse $\mathrm{N}^{\circ} 714$, Univ. Clermont-Ferrand, France. 
BARAZZONE P., GORDEN P., CARPENTIER J. L., ORCI L., FREYCHET P., CANIVET B., 1980. Binding, internalization and lysosomal association of ${ }^{125}$-glucagon in isolated rat hepatocytes : a quantitative electron microscope autoradiographic study. J. clin. Invest., 66, 10811093.

BROCKMAN R. P., 1980. Rates of removal of exogenous and endogenous glucagon from the plasma of sheep in vivo. Aust. J. biol. Sci, 33, 531-537.

DENCKER H., HEDNET P., HOLST J., TRANBERG K. G., 1975. Pancreatic glucagon response to an ordinary meal. Scand. Gastroent., 10, 471-474.

DESBUQUOIS B., POSTEL-VINAY M. C., 1980. Receptor-mediated internalization of insulin, glucagon, growth hormone in intact rat liver. A biochemical study, 285-292. In D. BRANDENBURG, A. WOLLMER, Insulin, chemistry, structure and function of insulin and related hormones. W. de Gruyter et Co., Berlin, New York.

EISENSTEIN A. B., STRACK I., 1978. Increased glucagon secretion in protein-fed rats : effects of refeeding a normal diet. Soc. exper. Biol. Med., 158, 578-581.

EISENSTEIN A. B., STRACK I., GALLO-TORRES H., GEORGIADIS A., NEAL-MILLER O., 1979. Increased glucagon secretion in protein-fed rats : lack of relationship to plasma amino acids. Am. J. Physiol., 236, E20-E27.

FAFOURNOUX P., RÉMÉSY C., DEMIGNÉ C., 1982. Stimulation of amino acid transport into liver cells from rat adapted to high-protein diet. Biochem. J., 206, 13-18.

FEHLMANN M., LE CAM A., FREYCHET P., 1979. Insulin and glucagon stimulation of amino acid transport in isolated rat hepatocytes. J. biol. Chem., 254, 10431-10437.

FEHLMANN M., MORIN O., KITABGI P., FREYCHET P., 1981. Insulin and glucagon receptors of isolated rat hepatocytes : comparison between hormone binding and amino acid transport stimulation. Endocrinology, 109, 253-261.

FISHER M., SHERWIN R. S., HENDLER R., FELIG P., 1976. Kinetics of glucagon in man : effects of starvation. Proc. nat. Acad. Sci., 73, 1735-1739.

GENUTH S. M., 1972. Metabolic clearance of insulin in man. Diabetes, 21, 1003-1012.

GRIZARD J., PRUGNAUD J., ARNAL M., PION R., 1975. Effet de l'insuline sur la composition corporelle et les teneurs en acides aminés libres du sang, du foie et du muscle du rat en croissance soumis à une restriction énergétique. Ann. Biol. anim. Bioch. Biophys., 15, 569582.

HAYASHI K., 1982. Insulin insensitivity and hyposuppressibility of glucagon by hyperglycemia in aged Wistar rats. Gerontology, 28, 10-18.

HENRY Y., RÉRAT A., 1965. Ingestion spontanée d'éléments énergétiques en régimes mixtes et séparés chez le rat en croissance. Ann. Biol. anim. Bioch. Biophys., 5, 283-292.

JARRIGE J. F., BOUCHER D., LEINOT M., 1978. Cathétérismes vasculaires chroniques chez le Rat. Adaptation aux injections et prélèvements sanguins semi-continus pour études hormonales. C. R. Soc. Biol., 172, 919-926.

JARROUSSE C., LARDEUX B., BOURDEL G., GIRARD-GLOBA A., ROSSELIN G., 1980. Portal insulin and glucagon in rats fed proteins as a meal: immediate variations and circadian modulations. J. Nutr., 110, 1764-1773.

JASPAN J. B., HUEN A., MORLEY C. G., MOOSA A. R., RUBENSTEIN A. H., 1977. The role of liver in glucagon metabolism. J. clin. Invest., 60, 421-428.

JASPAN J. B., KUKU S. F., LOCKER J. D., HUEN A. H. J., EMMANOUEL D. S., KATZ A. I., RUBENSTEIN A. H., 1976. Heterogeneity of plasma glucagon in man. Metabolism, 25, 1397-1401.

JASPAN J. B., POLONSKY K. S., LEWIS M., PENSLER J., PUGH W., MOOSA A. R., RUBENSTEIN A. H., 1981. Hepatic metabolism of glucagon in the dog. Contribution of the liver to overall metabolic disposal of glucagon. Am. J. Physiol,, 240, E233-E244.

LE CAM A., FREYCHET P., 1976. Glucagon stimulates the system for neutral amino acid transport in isolated hepatocytes of adult rat. Biochim. biophys. Res. Comm., 72, 893-901.

LEFEBVRE P. J., LUYCKX A. S., 1976. Plasma glucagon after kidney exclusion. Experiments in somatostatin-infused and in eviscerated dogs. Metabolism, 25, 761-767.

LEFEBVRE P. J., LUYCKX A. S., NIZET A. H., 1974. Renal handling of endogenous glucagon in the dog. Comparison with insulin. Metabolism, 23, 753-761.

MORIN O., FEHLMANN M., FREYCHET P., 1982. Binding and action of insulin and glucagon in 
monolayer cultures and fresh suspensions of rat hepatocytes. Mol. cell. Endocrinol., 25, 339-352.

NOTTEY J. J., ROSSELIN G., 1971. Monoiodoglucagon : préparation isolement, identification, contrôle radio-immunologique. C. R. Acad. Sci., Paris, Sér. D, 273, 2118-2121.

PARILLA R., JIMENEZ I., AYUSO-PARILLA M., 1975. Glucagon and insulin control of gluconeogenesis in the perfused isolated rat liver. Effects on cellular metabolite distribution. Eur. J. Biochem., 56, 375-383.

PARILLA R., JIMENEZ M. I., AYUSO-PARILLA M. S., 1976. Cellular redistribution of metabolites during glucagon and insulin control of gluconeogenesis in the isolated perfused rat liver. Arch. Biochem. Biophys., 174, 1-12.

PAWLAK M., PION R., 1968. Influence de la supplémentation des protéines de blé par des doses croissantes de lysine sur la teneur en acides aminés libres du sang et du muscle du rat en croissance. Ann. Biol, anim. Bioch. Biophys., 8, 517-530.

PÉRET J., FOUSTOCK S., CHANEZ M., BOIS-JOYEUX B., ASSAN R., 1981. Plasma glucagon and insulin concentrations and hepatic phosphoenolpyruvate carboxykinase and pyruvate kinase activities during and upon adaptation of rats to a high protein diet. J. Nutr., 111, 11731184.

SHERWIN R. S., BASTL C., FINKELSTEIN F. O., FISHER M., BLACK H., HENDLER R., FELIG P., 1976. Influence of uremia and hemodialysis on the turnover and metabolic effects of glucagon. J. clin. Invest., 57, 722-731.

SHERWIN R. S., KRAMER K. J., TOBIN J. D., INSEL P. A., LILJENQUIST J. E., BERMANN M., ANDRES R., 1974. A model of kinetics of insulin in man. J. clin. Invest., 53, 1481-1492.

SNEDECOR G. W., COCHRAN W. G., 1971. Méthodes statistiques, Acta Editions, Paris.

SODOYEZ J. C., SODOYEZ-GOFFAUX F., THIRY-MORIS Y. M., 1980. Kinetics of insulin binding to its receptors in vivo : effects of fasting, 293-300. In BRANDENBURG D., WOLLMER A., Insulin, chemistry, structure and function of insulin and related hormones. W. de Gruyter and Co., Berlin, New York.

TIEDGEN M., SEITZ H. J., 1980. Dietary control of circadian variations in serum insulin, glucagon and hepatic cyclic AMP. J. Nutr., 110, 876-882.

VALVERDE I., DOBBS R., UNGER R. H., 1975. Heterogeneity of plasma glucagon immunoreactivity in normal, depancreatized and alloxan-diabetic dogs. Metabolism, 24, 1021-1028.

VALVERDE I., VILLANUEVA M. L., 1976. Heterogeneity of plasma immunoreactive glucagon. Metabolism, 25, 1393-1395.

VAN HOORN W. A., VINIK A. I., VAN HOORŃ-HICKMAN R., 1978. The metabolic clearance of endogeneous immunoreactive glucagon and exogenous glucagon in pancreatectomized and sham-operated pigs. Endocrinology, 103, 1084-1089.

ZELEZNIK A. J., ROTH J., 1978. Demonstration of the insulin receptor in vivo in rabbits and its possible role as a reservoir of the plasma hormone. J. clin. Invest., 61, 1363-1374. 